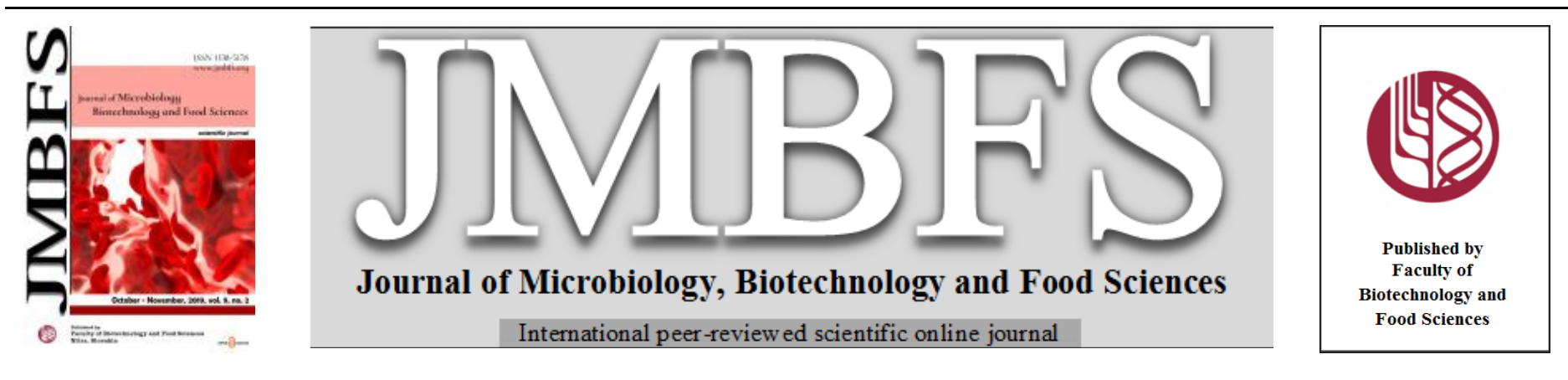

\title{
OPTIMIZATION OF ENVIRONMENTAL GROWTH PARAMETERS FOR BIODIESEL PRODUCING BACTERIA RHODOCOCCUS OPACUS USING RESPONSE SURFACE METHODOLOGY
}

\author{
Kulvinder Bajwa ${ }^{1 *}$, Narsi R. Bishnoi ${ }^{1}$, Saloni Gupta ${ }^{1}$, Silambarasan Tamil Selvan ${ }^{2}$ \\ Address(es): \\ ${ }^{1}$ Department of Environmental Science and Engineering, Guru Jambheshwar University of Science and Technology, Hisar, 125001, Haryana, India. \\ ${ }^{2}$ Department of Microbiology, School of Biosciences, Periyar University, Salem, 636011, Tamil Nadu, India.
}

*Corresponding author: kulvinderbajwa3@gmail.com

doi: 10.15414/jmbfs.2020.9.5.927-931

\section{ARTICLE INFO}

Received 8. 3. 2018

Revised 20. 10. 2019

Accepted 23. 10. 2019

Published 1. 4. 2020

Regular article

OPEN $\partial_{\text {AcCESS }}$

\begin{abstract}
Back ground: Rising level of carbon dioxide, increasing demands and value of fuel, generation of waste are the key issues of the modern society. Biodiesel is an alternate to standard fossil fuel. Currently, it's primarily made from vegetable oils associated consequently it's an adverse impact on food security. Lipids from oleaginous microorganisms (e.g. microalgae, bacteria, fungi and yeasts) may well be an alternate feedstock for biodiesel production and therefore the growth and lipid accumulation of Rhodococcus opacus was studied under different environmental conditions.

Results: The current aim of the study is to utilized Box Behnken Design (BBD) of the response surface methodology, for identifying optimum levels of particular variables. BBD design was performed on oleaginous bacterium, Rhodococcus opacus considering $\mathrm{pH}$, temperature and incubation period as independent variables. Lipid and biomass contents were analyzed as response variables. A second order polynomial model produced a satisfactory results of the experimental data with regard to biomass yield and lipid content $\%\left(\mathrm{R}^{2}=\right.$ $98,04,96.96(\mathrm{P} \leq 0.01)$. Optimum results of the experiments were $3.82 \mathrm{gL}^{-1}$ biomass and lipid content $33.55 \%$ at optimized conditions pH-7, temperature- $30^{\circ} \mathrm{C}$ and incubation time - $72 \mathrm{hrs}$. Results of predicted and actual response were differing with 2 to $3 \%$ and desirability of model $98 \%$.
\end{abstract}

Keywords: Rhodococcus sp. 16sRNA, Response surface methodology, Box Behnken design, biomass, lipid

\section{INTRODUCTION}

Elevated concentration carbon dioxide $\left(\mathrm{CO}_{2}\right)$ emission due to standard fossil fuel burning degrading eological environment; resulted shift in global climate, which is the main concern of the world (Kumar et al., 2018). Fossil fuel is depleting very fast and cost is increasing, therefore, there is an urgent need to develop methods for low carbon fuel i.e. biofuel or biodiesel (Kumar \& Thakur, 2018) Biodiesel is a renewable fuel that can potentially be produced in microbes cost effectively and environment friendly (Papanikolaou $\boldsymbol{e t}$ al., 2008; Easterling $\boldsymbol{e} t$ al., 2009; Cho \& Park, 2018). Microbial community such as microalgae cyanobacteria,oleaginous microorganisms, oil from seeds of green plants and waste cooking oils are used for biodiesel production (Kumar \& Thakur, 2018). Microorganisms contain lipid in their cytoplasmic membrane therefore considered as rich sources of oils and fats for biodiesel production. (Molina $\boldsymbol{e t}$ al., 2017). Biodiesel comprises of fatty acid methyl esters, originating from vegetable oils and animal fats mainly by trans-esterification of triacylglycerols (TAGs) or from free fatty acids has drawn attention as an ecofriendly, renewable substitute, biodegradable and nontoxic fuel (Easterling et al., 2009; Papanikolaou et al., 2008). Furthermore within the field of biodiesel not only algal biofuel of conventional energy resources, microorganism oils even have been gaining a lot of attention as a supplier of novel oils. Bacterial lipids applicable for renewable fuels production and chemicals derived from biological oils or fats (Castro et al., 2016). Additionally, they have numerous benefits, such as shorter life span, lesser laborious, season and climate, easy cultivation (Hidalgo et al., 2013; Shruthi et al., 2014). According to Papanikolaou and Aggelis, microorganism characterized as oleaginous and their oil as single cell oil, unicellular oil or microbial oil because they have accumulation capabilty of oil more than 20-25\% as dry cellular biomass (Papanikolaou \& Aggelis, 2011) Further more, certain genera of bacteria belonging to actinomycetes such as Mycobacterium, Rhodococcus, Gordonia, Streptomyces, Nocardia, Dietzia have potential of accumulating lipid in their cells and TAGs under nitrogen-stress conditions (Zhang et al., 2011; Wang \& Pan, 2019). Additionally, oleaginous bacteria having capacity to yield storage lipid, under some growth-restricted conditions also produce special kind of lipids, such as polyhydroxy-alkanoates (PHA) and poly 3-hydroxybutyrate (PHB) and other as cyoplasmic intracellular oil (Mamatha, 2009; Papanikolaou \& Aggelis, 2011; Bajwa \& Bishnoi, 2016). It has various impending commercial applications in pharmaceuticals, nutraceuticals industry, rich source of feed for aquaculture and biofuel production (Lewis et al., 2000; Peng, \& Chen, 2008; Ongmali et al., 2014). Many environmental factors affect physico-chemical properties of membrane and consequently their functioning which include pressure, $\mathrm{pH}$, temperature, water activity, ions, nutrients, enzymatic activity, microbial growth phase and xenobiotics compounds (Mrozik et al., 2004). Many changes in bacterial fatty acid composition and membrane fluidity occur in response to temperature fluctuations. As growth temperature rises, it is common to observe an increase of the proportion of long-chain and saturated fatty acids within the membrane (Mrozik et al., 2004)

Response surface methodology is a novel arithmetical design employed to evaluate problems where in the response is dependent on several independent variables with an objective to maximize the process variables for achieving optimum response (Box \& Behnken, 1960). RSM uses quantitative data from experimental conditions to analysis and solve multivariate equations (Gorret $\boldsymbol{e t}$ al., 2004; Tokcaer et al., 2006). RSM is very helpful tool in reduction of experiments as compared to manual practises eventually saving chemicals, time and labor. Furthermore, it offers a rapid and unfailing prediction of response, making it a beneficial option for experimental design (Singh et al., 2013). The Box Behnken design was taken as it fulfilled most of the requirement for interaction study for various factors (Gorret $\boldsymbol{e t}$ al., 2004; Tokcaer et al., 2006; Sigh et al., 2013). Thus the aim of present study is to evaluate the various environmental growth parameters viz. $\mathrm{pH}$, temperature and incubation on biomass yield and lipid content using Response surface methodology for oleaginous Rhodococcus sp.

\section{MATERIAL AND METHODS}

Isolation of genomic DNA from bacterial strain and 16s rRNA sequence determination and phylogenetic analysis

Extraction of genomic DNA was from bacterial strain was performed by using Cetyl trimethyl ammonium bromide (CTAB) method (Ausubel et al.,1987). 
After DNA extraction, $800 \mathrm{mg}$ of agarose in $100 \mathrm{ml} 1 \mathrm{X}$ TAE followed by heating in microwave and added 2 drops of ethidium bromide poured into Gel casting Tray. The amplification was conducted with Universal primers designed to anneal the conserved regions of bacterial 16S rRNA genes (Khalil, 2011). The PCR product of $16 \mathrm{~S}$ rDNA was sequenced by Geneombio Technology Pvt. Ltd Pune (Maharashtra). Nucleotide sequence was analyzed and compared with Gen Bank nucleotide sequence database using the Basic Local Alignment Tool (BLASTn).

\section{Biomass estimation}

Bacterial strain was cultured in MSM broth. Composition of MSM medium given in Table.1.Growth of experimental bacteria in MSM media was measured every 3 hours until 96 hours of the cultivation time and determined dry cell weight and optical density at $600 \mathrm{~nm}$. There was a linear relationship between dry weight and OD $600 \mathrm{~nm}$ as linear regression equation. Standard linear regression curve prepared by dilution ranging between 0.2 to 1 (Tapia et al., 2012), y $=0.2425 \mathrm{x}$ $+0.2615, \mathrm{R}^{2}=0.9923$

Table 1 Composition of minimum salt medium

$\begin{array}{lc}\mathrm{KH}_{2} \mathrm{PO}_{4} & 2 \\ \mathrm{~K}_{2} \mathrm{HPO}_{4} & 7 \\ \mathrm{ZnCl}_{2} & 0.01 \\ \mathrm{MgCl}_{2} & 0.20 \\ \mathrm{FeCl}_{3} & 0.01 \\ \mathrm{MnCl}_{2} \cdot 4 \mathrm{H}_{2} \mathrm{O} & 0.01 \\ \mathrm{Na}_{2} \mathrm{SO}_{4} & 0.20 \\ \mathrm{NH}_{4} \mathrm{NO}_{3} & 1.0 \\ \mathrm{Yeast} \mathrm{extract} & 0.006 \\ \mathrm{CaCl}_{2} & 0.01\end{array}$

\section{Determination of growth and lipid content gravimetrically}

Lipid extraction was performed with modified Bligh and Dyer Protoco (Chloroform Methanol: Water) in ratio 1:2:08) respectively for bacterial cells cultivated in Minimal salt medium. Bacterial cells were collected by centrifugation at 5,000 rpm for $15 \mathrm{~min}$. The cell pellet was washed with $40 \mathrm{~mL}$ of distilled water. The washed-cell pellet was freeze-dried, held in desiccator until constant mass was attained (usually $24 \mathrm{~h}$ ) and weighed to estimate its dry cell weight, followed by extraction with a mixture of chloroform, methanol and water (1:2:0.8, volume ratio). Further with addition of chloroform, methanol and water to reach a ratio of 1:1:0.9 (Papanikolaou et al., 2002). The solvent mixture containing extracted lipid was centrifuged and lipid layer was pooled by micropipette and the solvent removed in a desiccator. The dry lipid was weighed. Lipid content relative to dry cell weight was determined.

Optimization of $\mathrm{pH}$, temperature and incubation period process variables for the bacterial growth using box behnken design

RSM is a novel arithmetical design employed to evaluate problems wherein the response is dependent on several independent variables with an objective to maximize the process variables for achieving optimum response (Box, \& Behnken, 1960). The experimental design consisted of factors: $\mathrm{pH}$, incubation temperature $\left({ }^{\circ} \mathrm{C}\right)$, incubation time (Hours) (Table 2). Seventeen experiments were designed by Design Expert 7.0.0 box-Behnken model and conducted at various culture conditions as per experimental set up. Second order polynomial equation was used in order to find relationship between variables and responses. The regression equation coefficients were calculated and the data were fitted to a second order polynomial equation The adequacy of model was evaluated by coefficient of determination $\left(\mathrm{R}^{2}\right)$ and model $\mathrm{P}$ value. The analysis of variance (ANOVA) of various responses for lipid productivity (dcw \%), biomass $\left(\mathrm{gL}^{-1}\right)$ by using RSM (Singh et al., 2013).

Table 2 Three independent process variables used in RSM in terms of coded factors in Box-Behnken design for Rhodococcus opacus

\begin{tabular}{|c|c|c|c|c|}
\hline Factors & Process variable & Low $(-1)$ & Medium (0) & High (+1) \\
\hline $\mathbf{A}$ & $\begin{array}{l}\text { Incubation period } \\
\text { (hrs) }\end{array}$ & 24 & 72 & 120 \\
\hline B & Temperature $\left({ }^{\circ} \mathrm{C}\right)$ & 20 & 30 & 40 \\
\hline $\mathbf{C}$ & $\mathrm{pH}$ & 5 & 7 & 9 \\
\hline
\end{tabular}

\section{RESULT AND DISCUSSION}

\section{6s rRNA sequence determination and phylogenetic analysis}

Comparision of $16 \mathrm{~S}$ rRNA gene sequence obtained from the experimental species was done with other bacterial sequences by using NCBI mega BLAST.
Phylogenetic tree based on 16S RNA was constructed which showed that this isolate has $99 \%$ sequences similarity with Rhodococcus opacus (Figure 1).

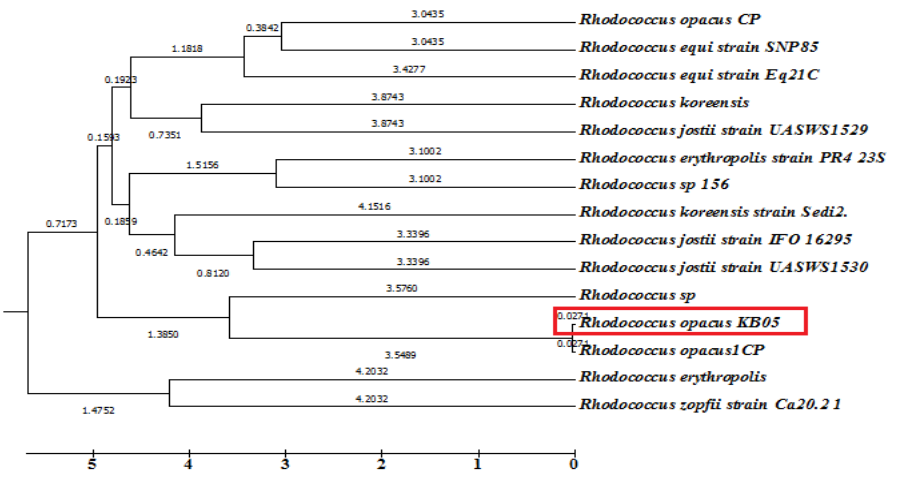

Figure 1 Construction of phylogenetic tree based on 16S rRNA gene sequences by neighbour joining method showing the relationship of Rhodococcus sp. with other universal identified species

Table 3 Box Behnken model for combined effect of $\mathrm{pH}$, temperature and incubation period in Rhodococcus opacus

\begin{tabular}{lccccc}
\hline Run & $\begin{array}{c}\text { Temperature } \\
\left({ }^{\circ} \mathbf{C}\right)\end{array}$ & $\mathbf{p H}$ & $\begin{array}{c}\text { Incubation } \\
\text { period(Hrs) }\end{array}$ & Biomass $\mathbf{g L}^{-\mathbf{1}}$ & Lipid \% \\
\hline 1 & 20 & 5 & 24 & 2.351 & 27.14 \\
2 & 30 & 7 & 72 & 3.828 & 33.55 \\
3 & 30 & 9 & 72 & 2.86 & 30.54 \\
4 & 30 & 5 & 72 & 2.94 & 29.73 \\
5 & 20 & 9 & 120 & 3.48 & 27.69 \\
6 & 40 & 7 & 72 & 3.5 & 32.12 \\
7 & 40 & 9 & 120 & 3.089 & 31.45 \\
8 & 20 & 7 & 72 & 3.62 & 30.65 \\
9 & 30 & 7 & 72 & 3.83 & 33.549 \\
10 & 30 & 7 & 72 & 3.829 & 33.551 \\
11 & 30 & 7 & 72 & 3.83 & 33.55 \\
12 & 20 & 9 & 24 & 2.661 & 26.58 \\
13 & 30 & 7 & 120 & 3.7 & 31.4 \\
14 & 40 & 5 & 120 & 3 & 31.019 \\
15 & 40 & 5 & 24 & 2.56 & 26.251 \\
16 & 30 & 7 & 72 & 3.832 & 33.55 \\
17 & 20 & 5 & 120 & 3.299 & 23.72 \\
18 & 30 & 7 & 24 & 3.5 & 28.6 \\
19 & 40 & 9 & 24 & 2.7 & 22.51 \\
20 & 30 & 7 & 72 & 3.83 & 33.55 \\
\hline & & & & & \\
\hline
\end{tabular}

Effect of mutual optimized process variables on various growth factors of Rhodococcus opacus

The growth of Rhodococcus opacus was studied by optimum culture parameter i.e. $\mathrm{pH}$, temperature and incubation period. All experiments were designed by using box behnken model, around 20 sets of experiments designed to fit a second order polynomial equation for optimizing the growth of Rhodococcus opacus in respect to concentration of lipid and biomass. The minimum, central and maximum process variables such as $\mathrm{pH} 5$ to 9 , temperature 20 to $40^{\circ} \mathrm{C}$, incubation period 24 to $120 \mathrm{hrs}$ were used in the BBD for various responses and their impacts on biomass yield and lipid content Rhodococcus opacus (Table 3) (Kirrolia et al.,2014)

ANOVA for the response surface quadratic model of various growth parameters in Rhodococcus opacus were depicted in Table 4. The test statistic for lack-of-fit is the ratio between the lack-of-fit mean square and the pure error mean square (Singh et al.,2013; Kirrolia et al.,2014). Lack of fit, non significant value has shown the validity of the quadratic model for various responses of the experimental culture. F-test statistic used in order to determine lack of fit error whether it is significant or not. The value $\mathrm{R}^{2}-98.04 \%$, Adj $\mathrm{R}^{2} 99.03 \%$ for biomass and $\mathrm{R}^{2}-99.96 \%$, Adj $\mathrm{R}^{2}-99.98 \%$ for lipid content showed that they were found to be reasonable agreement with better reliabilty of model. All the $\mathrm{R}^{2}$ values of the experimental data were found to be close to 1.0 indicated that suitabilty of the model. Signal to noise ratio was measured by adequate precision. Signal to noise ratio greater than 4 is suitable for model validation. A ratio of $7.105,23.7$ of biomass and lipid model indicated an adequate signal which implied that these models can be used to design three dimensional graphs. Low standard deviation value with coefficient variation of biomass, lipid including $0.27,0.66$ and $7.96 \%, 6.22 \%$ which implied that model is suitable for present study. For biomass only linear $\mathrm{AB}, \mathrm{AC}, \mathrm{BC}$, quadractic $\left(\mathrm{A}^{2}, \mathrm{~B}^{2}, \mathrm{C}^{2}\right)$ are 
significant model terms based on the p-value. For lipid accumulation linear (A, C) mutual $(\mathrm{AB}, \mathrm{AC}, \mathrm{BC})$ quadractic $\left(\mathrm{A}^{2}, \mathrm{~B}^{2}, \mathrm{C}^{2}\right)$ are significant model terms. An flat inverted umbrella shaped standard error graph is desirable for $\mathrm{BBD}$ design with no sign of data interpretation (Fig. 2).The final responses in term of coded factors for lipid content and biomass yield are depicted in the equations below: (Kirrolia et al.,2013)

\section{Model equations in terms of coded factors:}

Biomass $=+3.17+0.42 * \mathrm{~A}+0.14 * \mathrm{~B}+0.27 * \mathrm{C}-0.12 * \mathrm{~A} * \mathrm{~B}+0.1 * \mathrm{~A} * \mathrm{C}+0.06 * \mathrm{~B} * \mathrm{C}-$ $0.46 * \mathrm{~A}^{2}-0.4 * \mathrm{~B}^{2}-0.29 * \mathrm{C}^{2}$

Lipid $\quad(\%) \quad=\quad+33.53+0.76 * \mathrm{~A}-9.000 \mathrm{E}-003 * \mathrm{~B}+1.42 * \mathrm{C}-$ $0.84 * \mathrm{~A} * \mathrm{~B}+2.00 * \mathrm{~A} * \mathrm{C}+1.09 * \mathrm{~B} * \mathrm{C}-2.12 * \mathrm{~A}^{2}-0.87 * \mathrm{~B}^{2}-3.50 * \mathrm{C}^{2}$

..........2

Statistical exploration of positive linear coefficient showed that culturing time was the most significant factor affecting the cell growth variables responses in experimental culture (Eq. 1 to 2). Hence the relationship of biomass and lipid with process variables such as $\mathrm{pH}$, temperature and incubation period in Rhodococcus opacus can be interpretated from model equations presented in coded factors. Higher values of $\mathrm{pH}$,temperature in linear coefficient term illustrated the significantly positive output of the variables on all the responses (Singh et al.,2014).Positive linear coefficient value for $\mathrm{pH}$,temperature and incubation period indicated that all three variables showed their maximum effect at various optimum concentrations. Positive values of $0.14,0.27,0.06$ for linear coefficient of temperature, $\mathrm{pH}$ and incubation period illustrated that significantly positivite effect of these factors on biomass production. The negative interactive coefficient data of independent variable (linear $\mathrm{C}$, quadratic, $\mathrm{B}^{2} \mathrm{C}^{2}$ ) on biomass yield was observed as a function of thesse variables by keeping all the variables at a fixed level. Similarly linear coefficients values of $\mathrm{pH}$ and temperature $(1.42$ 2.0,1.09) implied that these factors have significants effects on lipic accumulation. Three dimensional (3D) graphs were used to explore the sensitivity of the responses of two interacting variables by holding the other variables constant at central values (Kirrolia et al., 2013).The lipid accumulation and biomass yield assets of Rhodococcus opacus under different initial $\mathrm{pH}$ temperature and incubation period were shown in three dimensional graphs. Fig. 2 (A, B) which indicated higher temperature $30^{\circ} \mathrm{C}$ with optimum $\mathrm{pH} 7$ and incubation period of $72 \mathrm{hrs}$ has much significant $(\mathrm{P} \leq 0.05)$ effects on biomass and total lipid production in Rhodococcus opacus. The higher $\mathrm{pH}$ and temperature has cellular growth retarding effects on biomass and lipid production (Leesing, \& Baojungharn, 2011; Enshaeieh et al., 2013; Dias et al., 2016; Poontawee $e t$ al.,2017). $\mathrm{pH}$ has been described as an important factor that strongly interferes in the lipid accumulation in oleaginous microorganism (Papanikolaou \& Aggelis, 2010)

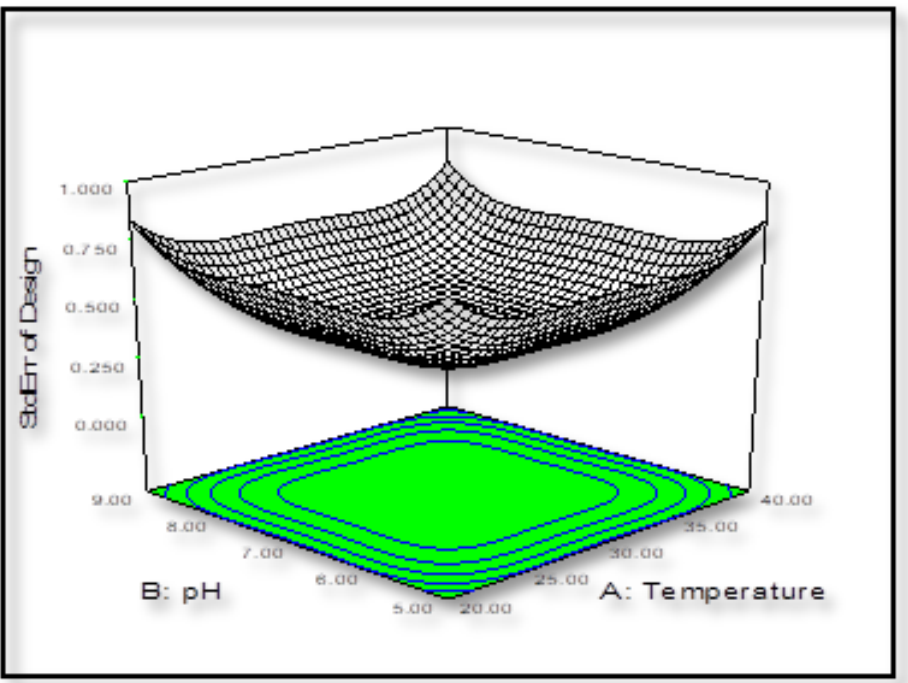

Figure 2 Three dimensional plot of standard error design of the model with $\mathrm{pH} 7$ and temperature $30^{\circ} \mathrm{C}$, keeping incubation period constant

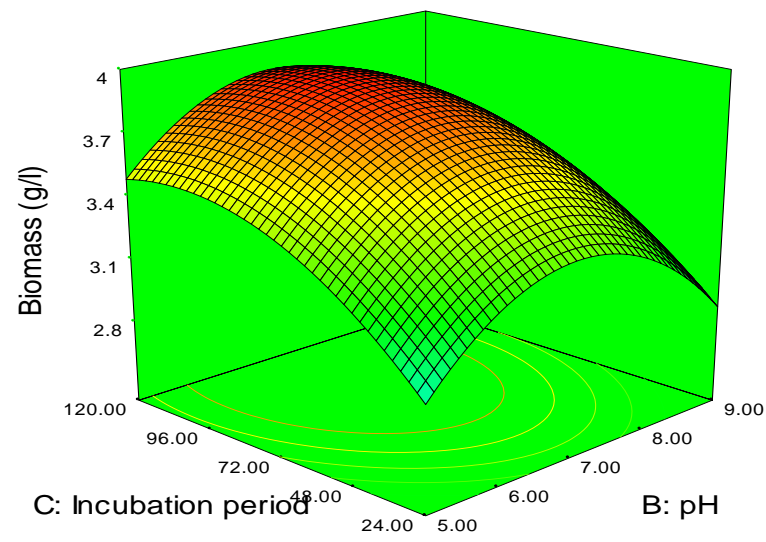

$\left(\mathbf{A}_{1}\right)$

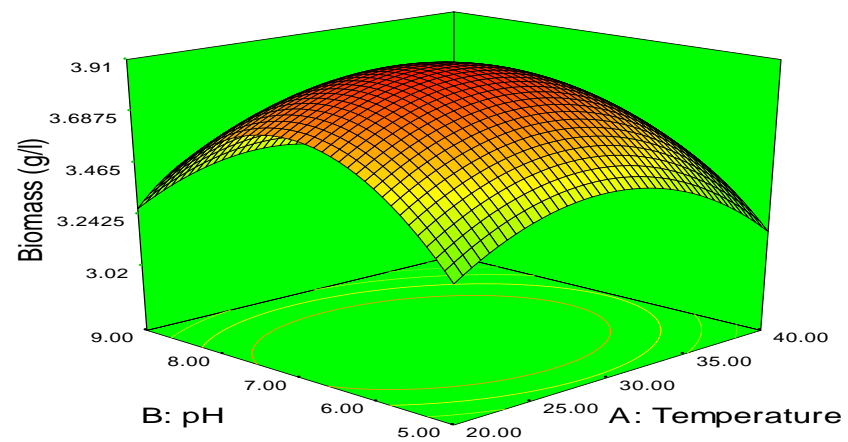

$\left(\mathbf{A}_{2}\right)$

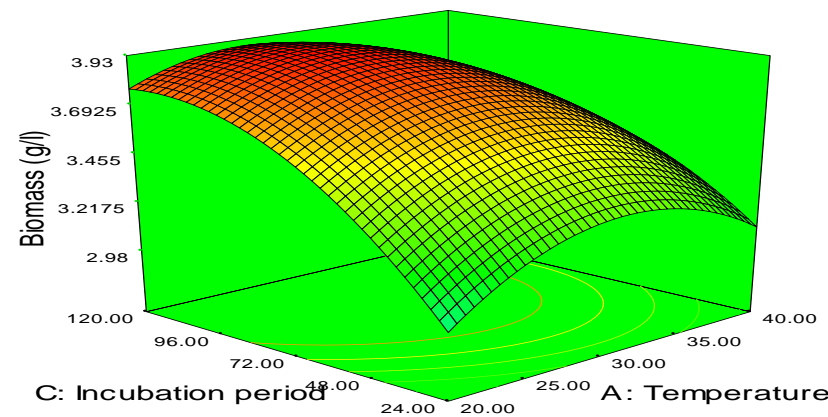

$\left(\mathbf{A}_{3}\right)$

Figure $2 \mathrm{~A}\left(\mathrm{~A}_{1}, \mathrm{~A}_{2}, \mathrm{~A}_{3}\right)$ Three dimensional response surface plots showing mutual interaction of $\mathrm{pH}$, temperature and incubation period on lipid content \% (B)
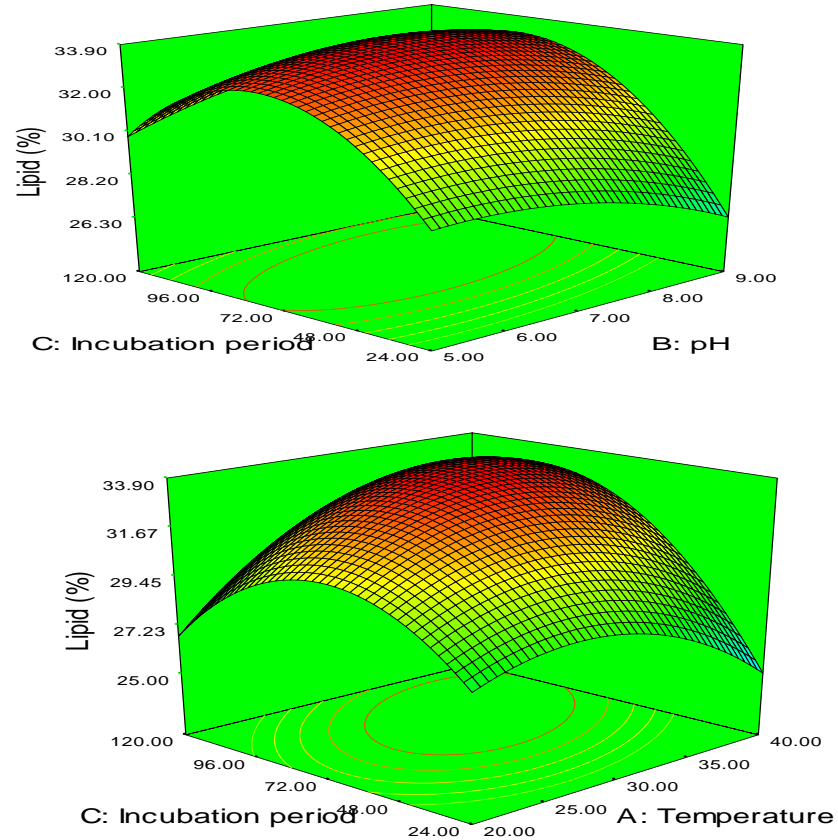

(B) 
$\left(\mathbf{B}_{3}\right)$

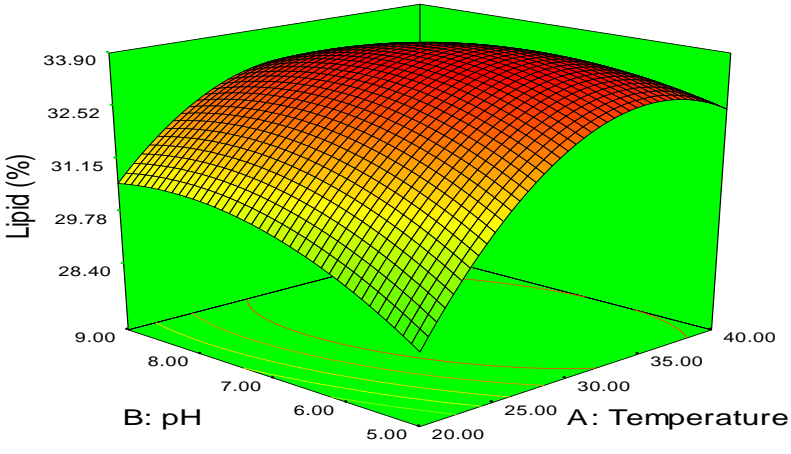

Figure $2 \mathrm{~B}\left(\mathrm{~B}_{1}, \mathrm{~B}_{2}, \mathrm{~B}_{3}\right)$ Three dimensional response surface plots showing mutual interaction of $\mathrm{pH}$, temperature and incubation period on lipid content $\%$ As it is cleared from the Figure $2 \mathrm{~A}\left(\mathrm{~A}_{1}, \mathrm{~A}_{2}, \mathrm{~A}_{3}\right)$ that with increasing $\mathrm{pH} 5$ to 9 there was corresponding increase in biomass yield and optimum result found at $\mathrm{pH}$ 7. According to observation of another researchers that temperature has significant effect on free fatty acid of microbial oil and lipid content, the optimum temperature responsible for the synthesis of oleaginous microbial fat, temperature range varies for both fat synthesis and cell growth (Papanikolaou $\boldsymbol{e} t$ al., 2002; Zhao et al., 2010

Table 4 ANOVA for the response surface quadratic model of biomass yield and lipid accumulation in Rhodococcus opacus

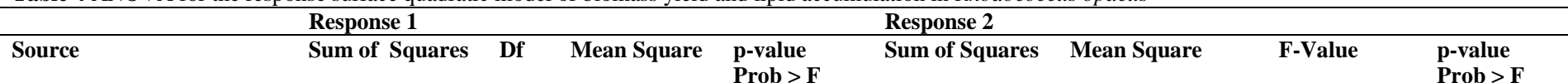

\begin{tabular}{|c|c|c|c|c|c|c|c|c|}
\hline Model & 4.220124 & 1 & 0.468903 & $<0.0001$ & 234.6348 & 26.07054 & 5990.365 & $<0.0001$ \\
\hline A-Temperature & 0.031584 & 1 & 0.031584 & $<0.0001$ & 5.73049 & 5.73049 & 1316.725 & $<0.0001$ \\
\hline B-pH & 0.01296 & 1 & 0.01296 & $<0.0001$ & 0.00081 & 0.00081 & 0.186118 & $<0.0001$ \\
\hline C-Incubation period & 0.781762 & 1 & 0.781762 & $<0.0080$ & 20.15832 & 20.15832 & 4631.884 & $<0.0001$ \\
\hline $\mathrm{AB}$ & 0.00858 & 1 & 0.00858 & $<0.0001$ & 5.6448 & 5.6448 & 1297.036 & $<0.0001$ \\
\hline $\mathrm{AC}$ & 0.109981 & 1 & 0.109981 & $<0.0001$ & 32.07204 & 32.07204 & 7369.362 & $<0.0001$ \\
\hline $\mathrm{BC}$ & 0.00405 & 1 & 0.00405 & $<0.0001$ & 9.465601 & 9.465601 & 2174.961 & $<0.0001$ \\
\hline $\mathrm{A}^{\wedge} 2$ & 0.204477 & 1 & 0.204477 & $<0.0001$ & 12.3543 & 12.3543 & 2838.713 & $<0.0001$ \\
\hline $\mathrm{B}^{\wedge} 2$ & 0.514837 & 1 & 0.514837 & $<0.0001$ & 2.079301 & 2.079301 & 477.7719 & $<0.0001$ \\
\hline $\mathrm{C}^{\wedge} 2$ & 0.148887 & 10 & 0.148887 & $<0.0001$ & 33.77506 & 33.77506 & 7760.673 & $<0.0001$ \\
\hline Residual & 0.716513 & 5 & 0.071651 & & 0.043521 & 0.004352 & & \\
\hline Lack of Fit & 0.716504 & 5 & 0.143301 & $<0.0001$ & 0.043519 & 0.008704 & 21759.39 & $<0.0001$ \\
\hline Pure Error & 8.83E-06 & 19 & $1.77 \mathrm{E}-06$ & & $2.00 \mathrm{E}-06$ & $4.00 \mathrm{E}-07$ & & \\
\hline Core Total & 4.936637 & & & & 234.6784 & & & \\
\hline
\end{tabular}

Response 1- Biomass ( $\mathrm{R}^{2}-98.04 \%$, Adj.R ${ }^{2}: 99.03 \%$ ); Response 2- Lipid $\left(\mathrm{R}^{2}-99.96 \%\right.$, Adj.R $\left.{ }^{2}-99.98 \%\right)$

Kraisintu et al., (2010), obtained the highest lipid yield $\left(9.26 \mathrm{gL}^{-1}\right)$ and cellular lipid percentage (71.30\% of dry biomass) at medium pH 5.5 in oleaginous yeast. Komazawa et al., (2007) reported that for a Thraustochytrium strain, $\mathrm{pH}$ between 5.0 and 8.0 was optimum. Similar study was reported by Wu et al.,(2005) when $\mathrm{pH}$ was varied between $\mathrm{pH} 5$ to 8 , a maximum biomass and DHA yield was obtained from Schizochytrium sp. at pH 7.0. As presented in Fig. 2 (B) with increase in temperature subsequently decrease in lipid content in Rhodococcus opacus. According to Saxena et al., (2009), composition of lipid also varied at different temperatures as we found in our present work. Enshaeieh et al., (2013) found that $96 \mathrm{hrs}$ is optimum incubation period for lipid accumulation and biomass yield in Rodotorula $s p$. In contrary to our results, Vipra and his co-workers have been observed that highest lipid yield at culturing period (24 hrs) in oleaginous yeasts viz. Lipomyces lipofera cultures and Yarrowia lipolytica (Vipra et al., 2012). Hence shorter culture growth time is considered as ideal for potential industrial processes for lipid production (Holdsworth,1998). Papanikolaou et al., (2002) observed that reduction in lipid accumulation about $1 \mathrm{gL}^{-1}$ of Yarrowia lipolytica $\mathrm{M} 7$ when incubation time incceased from 72 hrs to $96 \mathrm{hrs}$ after increasing of incubation time from. Yarrowia lipolytica $\mathrm{M} 7$ produced significantly $(\mathrm{P} \leq 0.05)$ higher biomass and lipid yield upto 72 hours of period of incubation period as we observed in our results (Papanikolaou et al., (2002). Ongmali et al., (2014) found that oleaginous Aeromonas sp. showed enhanced cellular dry weight and lipid yield over a period of 72 hours.

\section{MODEL VALIDATION}

Box-Behnken design was implemented to screen the key process parameters and identify optimal values that contribute maximum biomass and lipid production (Ghosh et al., 2015). Experiments were run on optimum conditions suggested by model to evaluate the validity of the model (Sekhar et al., 2014). Optimum results of the experiments were $3.82 \mathrm{gL}^{-1}$ biomass and lipid content $33.55 \%$. Results of predicted and actual response were differing with 2 to $3 \%$ and desirability of model 98\%. Less than $10 \%$ difference in predicted and experimental response was found to suitable for model validation (Kumar \& Banerjee, 2013)

\section{CONCLUSION}

In conventional one-factor time experiments, a single factor varies; keeping other factors constant and the effect of interaction among the variables is ignored. The
RSM is a systematic statistical design approach, aimed at developing the relationships between process variables and responses in order to assemble for a better overall understanding with a minimum number of experiments (Kirrolia et al.,2013). Most importantly BBD generates appropriate statistical assets so that, for the suitability of quadratic model for data evaluation, only fraction of the trials requisite for a 3-level factorial (Singh $\boldsymbol{e t}$ al.,2014). RSM was successfully implemented for optimization of various culture growth variables such as $\mathrm{pH}$ temperature and incubation time. Rhodococcus opacus showed optimum results of the experiments were $3.82 \mathrm{gL}^{-1}$ biomass and lipid content $33.55 \%$ at $\mathrm{pH} 7$, temperature $30^{\circ} \mathrm{C}$ and incubation period $72 \mathrm{hrs}$. Results of predicted and actual response were differing with 2 to $3 \%$ and desirability of model $98 \%$. Results revealed that there were no significant variances between the predicted data for studied responses and experimental data obtained with optimum experimental conditions.

Conflict of interest :The authors disclosed that there was no conflicts of interest.

Acknowledgments: We have to express out our appreciation to Department of Environmental Science and Engineering, Guru Jambheshwar university of Science and Technology, Hisar (Haryana) for providing research assistance. The authors are also immensely thankful to the University Grant Commission, Maulana Azad fellowship for minority students, SRF) for the financial support.

\section{REFERENCES}

Ausubel, F.M., Brent, R.., Kingston, R..E., Moore, D.D., Seidman, J.G., Smith J.A., \& Stuhl, K (1987).Current protocol in molecular biology. Wiley, New York.

Bajwa, K., \& Bishnoi, N. R. (2016). Single cell oil of bacterial strains as a new source of high-value biodiesel! Isolation and screening for storage lipids in cytoplasm. Annals of Biology.32(1):1-6

Bligh, E. G., \& Dyer, W. J. (1959). A rapid method of total lipid extraction and purification. Canadian journal of biochemistry and physiology, 37(8), 911-917.

Box, G. E., \& Behnken, D. W. (1960). Some new three level designs for the study of quantitative variables. Technometrics, 2(4), 455-475.

Castro, A. R., Rocha, I., Alves, M. M., \& Pereira, M. A. (2016). Rhodococcus opacus B4: a promising bacterium for production of biofuels and biobased chemicals. AMB Express, 6(1), 1-11. https://doi.org/10.1186/s13568-016-0207-y 
Cho, H. U., \& Park, J. M. (2018). Biodiesel production by various oleaginous microorganisms from organic wastes. 256,502-508. Bioresource technology. https://doi.org/10.1016/j.biortech.2018.02.010

Dias, C., Silva, C., Freitas, C., Reis, A., \& da Silva, T. L. (2016). Effect of medium $\mathrm{pH}$ on Rhodosporidium toruloides NCYC 921 carotenoid and lipid production evaluated by flow cytometry. Applied biochemistry and biotechnology, 179(5),776-87. https://doi.org/10.1007/s12010-016-2030-y

Easterling, E.R., French, W.T., Hernandez, R., Licha, M .2009. The effect of glycerol as a sole and secondary substrate on the growth and fatty acid composition of Rhodotorula glutinis. Bioresour. Technol. 100, 356-361. https://doi.org/10.1016/j.biortech.2008.05.030

Enshaeieh, M., Abdoli, A., Nahvi, I. and Madani, M. (2013). Selection and optimization of single cell oil production from Rodotorula110 using environmental waste as substrate. J. Cell. Molecular Research, 4(2): 1-10. DOI: 10.22067/jcmr.v4i2.16979

Ghosh, S., Roy, S., \& Das, D. (2015). Improvement of biomass production by Chlorella sp. MJ 11/11 for use as a feedstock for biodiesel. Applied biochemistry and biotechnology, 175(7), 3322-3335. https://doi.org/10.1007/s12010-015-1503$\underline{8}$

Gorret, N., bin Rosli, S. K., Oppenheim, S. F., Willis, L. B., Lessard, P. A., Rha, C., \& Sinskey, A. J. (2004). Bioreactor culture of oil palm (Elaeis guineensis) and effects of nitrogen source, inoculum size, and conditioned medium on biomass production. Journal of biotechnology, 108(3), 253-263. https://doi.org/10.1016/j.jbiotec.2003.12.009

Hidalgo, P., Toro, C. \& Navia, R. (2013). Advances in direct transesterification microalgal biomass for biodiesel production. Reviews in Environmental Science anca Bio/Technology, 12(2), 179-199. https://doi.org/10.1007/s11157-013-9308-0

Holdsworth J. Ratledge C. Lipid turnover in oleaginous yeasts. Microbiology. (1988) 134(2):339-346. doi:10.1099/00221287-134-2-339

Khalil, A. (2011). Isolation and characterization of three thermophilic bacteria strains (lipase, cellulose and amylase producers) from hot springs in Saudi Arabia. African Journal of Biotechnology, 10(44), 8834-8839. http://dx.doi.org/10.5897/AJB10.1907

Kirrolia, A., Bishnoi, N. R., \& Singh, R. (2014). Response surface methodology as a decision-making tool for optimization of culture conditions of green microalgae Chlorella spp. for biodiesel production. Annals of microbiology, 64(3), 1133-1147. https://doi.org/10.1007/s13213-013-0752-4

Komazawa H, Kojima M, Aki T, Ono K, Kawakami M. U.S. (2007) Patent No. 7,259,006. Washington, DC: U.S. Patent and Trademark Office.

Kraisintu P, Yongmanitchai W, Limtong S. (2010). Selection and optimization for lipid production of a newly isolated oleaginous yeast, Rhodosporidium toruloides DMKU3-TK16. Kasetsart. J Nat. Sci.44:436-445.

Kumar, M., \& Thakur, I. S. (2018). Municipal secondary sludge as carbon source for production and characterization of biodiesel from oleaginous bacteria Bioresource Technology Reports, 4, 106-113. https://doi.org/10.1016/j.biteb.2018.09.011

Kumar, S. P., \& Banerjee, R. (2013). Optimization of lipid enriched biomass production from oleaginous fungus using response surface methodology. Indian J Exp Biol._51(11):979-83. http://hdl.handle.net/123456789/23466

Leesing, R., \& Baojungharn, R. (2011). Microbial oil production by isolated oleaginous yeast Torulaspora globosa YU5/2. World Academy Sci. Engine. Technol, 76(52), 799-803

Lewis, T., Nichols, P. D., \& McMeekin, T. A. (2000). Evaluation of extraction methods for recovery of fatty acids from lipid-producing micro heterotrophs Journal of Microbiological Methods, 43(2), 107-116. https://doi.org/10.1016/S0167-7012(00)00217-7

Mamatha, S. S. (2009). Polyunsaturated fatty acids (PUFAs) of Mucor sp. with special reference to Gamma Linolenic Acid (GLA) (Doctoral dissertation, University of Mysore).

Molina, E. C., Loperena, L., Hinzpeter, I., Pradel, P., Gordillo, F., Corsini, G., \& González, A. R. (2017). Isolation and molecular characterization of Thraustochytrium strain isolated from Antarctic Peninsula and its biotechnological potential in the production of fatty acids. Brazilian Journal of Microbiology. 48(4):671-679. http://dx.doi.org/10.1016/j.bjm.2017.01.011

Mrozik, A., Piotrowska-Seget, Z., \& Labuzek, S. (2004). Cytoplasmatic bacterial membrane responses to environmental perturbations. Polish Journal of Environmental Studies, 13(5), 487-494.

Ongmali, R., Phunpruch, S., \& Thawornchaisit, U. (2014). Cellular lipid production of a heterotrophic bacterium isolated from poultry processing wastewater. Songklanakar in Journal of Science \& Technology,1 (3) 1-20. http://www.sjst.psu.ac.th

Papanikolaou S., Fakas. S., Fick. M., Chevalot I., Panayotou, M.G.,Komaitis.M .M., Marc, I.e Aggelis, G.(2008). Biotechnological valorization of raw glycerol discharged after bio-diesel (fatty acid methyl esters) manufacturing process Production of 1,3-prppanediol,citric acid and single cell oil. Biomass and Bioenergy .32, 60-71. https://doi.org/10.1016/j.biombioe.2007.06.007

Papanikolaou, S., \& Aggelis, G. (2010). Yarrowia lipolytica: A model microorganism used for the production of tailor made lipids. European Journal of Lipid Science and Technology, 112(6), 639-654 https://doi.org/10.1002/ejlt.200900197
Papanikolaou, S., \& Aggelis, G. (2011). Lipids of oleaginous yeasts. Part I: Biochemistry of single cell oil production. European Journal of Lipid Science and Technology, 113(8), 1031-1051. https://doi.org/10.1002/ejlt.201100014 Papanikolaou, S., Chevalot, I., Komaitis, M., Marc, I., \& Aggelis, G. (2002). Single cell oil production by Yarrowia lipolytica growing on an industrial derivative of animal fat in batch cultures. Applied Microbiology and Biotechnology, 58(3), 308-312. https://doi.org/10.1007/s00253-001-0897-0

Peng, X., \& Chen, H. (2008). Rapid estimation of single cell oil content of solidstate fermented mass using near-infrared spectroscopy. Bioresource technology, 99(18), 8869-8872. https://doi.org/10.1016/j.biortech.2008.04.055 Poontawee, R., Yongmanitchai, W., \& Limtong, S. (2017). Efficient oleaginous yeasts for lipid production from lignocellulosic sugars and effects of lignocellulose degradation compounds on growth and lipid production. Process biochemistry, 53, 44-60. https://doi.org/10.1016/j.procbio.2016.11.013

Saxena RK, Anand P, Saran S, Isar J. (2009).Microbial production of 1, 3 propanediol: recent developments and emerging opportunities. Biotechnology advances. 27(6):895-913. https://doi.org/10.1016/j.biotechadv.2009.07.003

Sekhar, C. V., Pandurangadu, V., \& Subba Rao, T. (2014). Prediction of Mechanical properties of polymer composites reinforced with feather fibers of 'Emu'bird. In Applied Mechanics and Materials (592, 694-699). Trans Tech Publications.https://doi.org/10.4028/www.scientific.net/AMM.592-594.694

Shruthi, P., Rajeshwari, T., Mrunalini, B. R., Girish, V., \& Girisha, S. T. (2014). Evaluation of Oleaginous Bacteria for Potential Biofuel. Int. J. Curr. Microbiol. App. Sci, 3(9), 47-57. http://eprints-bangaloreuniversity.in/id/eprint/5032

Singh, R., Bishnoi, N. R. \& Kirrolia, A. (2013). Evaluation of Pseudomona caeruginosa an innovative bioremediation tool in multi metals ions from simulated system using multi response methodology. Bioresource technology, 138, 222234. https://doi.org/10.1016/j.biortech.2013.03.100

Tapia, E. V, Anschau, A., Coradini, A., Franco, T. T. and Deckmann, A. C.2012. Optimization of lipid production by the oleaginous yeast Lipomyces starkeyi by random mutagenesis coupled to cerulenin screening. AMB Express. 2, 64 https://doi.org/10.1186/2191-0855-2-64

Tokcaer, Z., Bayranktar, E., Mehmetoğlu, U., Özcengiz, G., Alaeddinoğlu, N.G., 2006. Response surface optimization of antidipteran delta-endotoxin production by Bacillus thuringiensis subsp. israelensis HD 500. Process Biochem.41, 350355. https://doi.org/10.1016/j.procbio.2005.02.030

Vipra AA, Desai SN, Roy P, Patil R, Raj JM, Narasimhaswamy N, Sriram B. (2012). Anti-staphylococcal activity of bacteriophage derived chimeric protein P128. BMC microbiology.12(1):1-10. https://doi.org/10.1186/1471-2180-12-41

Wang, Z., Li, N., \& Pan, X. (2019). Transformation of Ammonia Fiber Expansion (AFEX) corn stover lignin into microbial lipids by Rhodococcus opacus. Fuel, 240, 119-125. https://doi.org/10.1016/j.fuel.2018.11.081

Zhang, G., French, W. T., Hernandez, R., Alley, E., \& Paraschivescu, M. (2011) Effects of furfural and acetic acid on growth and lipid production from glucose and xylose by Rhodotorula glutinis. biomass and bioenergy, 35(1), 734-740. https://doi.org/10.1016/j.biombioe.2010.10.009

Zhang, J., Fang, X., Zhu, X.-L., Li, Y., Xu, H.-P., Zhao, B.-F., Chen, L. and Zhang, X.-D. 2011. Microbial lipid production by the oleaginous yeast Cryptococcus curvatus $\mathrm{O}_{3}$ grown in fed-batch culture. Biomass and Bioenergy. 35(5), 1906-1911. https://doi.org/10.1016/j.biombioe.2011.01.024

Zhao, C. H., Cui, W., Liu, X. Y., Chi, Z. M., \& Madzak, C. (2010). Expression of inulinase gene in the oleaginous yeast Yarrowia lipolytica and single cell oil production from inulin-containing materials. Metabolic engineering, 12(6), 510517. https://doi.org/10.1016/j.ymben.2010.09.001 